\title{
Back-Arc Opening and the Mode of Subduction
}

\author{
SEIYA Uyeda \\ Earthquake Research Institute, University of Tokyo, Tokyo, Japan
}

HIROO K ANAMORI

Seismological Laboratory. California Institute of Technology, Pasadena, California 91125

\begin{abstract}
Trench-arc systems (subduction zones) can be classified into two types depending on whether or not actively opening back-arc basins are associated with them. This suggests that subduction of an oceanic plate is not a sufficient condition for back-arc opening, though it may be necessary one. Mechanisms that cause the distinction between the two types have been investigated. Earthquake studies suggest that there is a significant difference in the mode of plate motion at interplate boundaries between the two types of trench-arc systems. Extreme cases are Chile, where plate motion is seismic, and the Marianas arc, where it is aseismic. This difference seems to indicate that the stress state in the back-arc area differs between the two types: compression in the Chilean type and tension in the Marianas type. This difference in the stress state is also manifested in other tectonic features, such as topography, gravity, volcanic activity, and crustal movement. Two possible mechanisms for the difference between the two types are suggested: (1) The nature of the contact zone between upper and lower plates changes from tight coupling (Chile) to decoupling (the Marianas) through the evolutionary process of subduction. The decoupling results in an oceanward retreat of the trench and back-arc opening. (2) The downgoing slab is anchored to the mantle, so that the position of a trench is also fixed with respect to the mantle. Since the motion in the mantle is slow compared to that of surface plates, it is the motion of the landward plate which controls the opening and nonopening of back-arcs.
\end{abstract}

\section{INTRODUCTION}

In plate tectonics, the fundamental process occurring under the trench-arc systems is the subduction of an oceanic plate. Small oceanic basins, such as the Japan Sea, Okhotsk Sea, and Philippine Sea are often found landward of arcs. The intent of the present paper is to discuss the genesis of these basins, called back-arc basins or marginal seas.

We first note the fact that not all the trench-arc systems have back-arc basins. The Peruvian and Chilean arcs do not have back-arc basins. The process of back-arc basin formation appears to be inactive at present in some arcs as in the case of the Japan Sea, whereas others are believed to have an actively opening back-arc basin, for example, the Mariana Trough [Karig, 1971a]. Any theory for the genesis of back-arc basins must account for this fact. Clearly, the subduction of an oceanic plate is not a sufficient condition for the formation of back-arc basins, although it may be a necessary one.

Several possibilities have been suggested to explain the origin of back-arc basins: (1) entrapment of a marginal part of preexisting ocean by the formation of an island arc: Aleutian Basin [Cooper et al., 1976] and west Philippine Sea [Uyeda and Ben-Avraham, 1972], (2) back-arc spreading caused by or related to subduction: Lau Basin and Mariana Trough [Karig. 1970, 1971a], Scotia Sea [Barker, 1970], and Japan Sea [Karig, 1971b; Matsuda and Uyeda. 1971], (3) opening related to 'leaky' transform fault: Gulf of California [Wilson, 1965] and Andaman Sea [Curray et al., 1979], (4) opening related to the subduction of a ridge: Japan Sea [Uyeda and Miyashiro, 1974], and (5) subsidence caused by oceanization of continental crust: Japan and Okhotsk seas [Beloussov and Ruditch, 1961].

Among the above possibilities, 1 is probably the likeliest mechanism provided that the age of the basin is older than that of the arc. The Mesozoic sequence of magnetic lineations in the Aleutian Basin is a notable example provided that the identifications, are correct. Possibilities 3 and 4 seem to be

Copyright @ 1979 by the American Geophysical Union. closely correlated with each other because, from geometrical considerations, it is clear that a subduction boundary can easily change to a 'leaky' transform boundary upon a collision of a spreading center with the trench. In fact, the opening of the Gulf of California may be an example of the combined effects of 3 and 4. Until 20 m.y. B.P. the East Pacific Rise was situated to the west of Baja California [Atwater, 1970] while now it is in the gulf in the form of a series of ridges and transforms. The ridge possibly died during its collision with the trench that existed to the west of Baja and reappeared in the former back-arc region by jumping rather than migrating under the Baja. The Andaman Sea may be another example [Eguchi et al., 1979]. Possibility 5 seems to have no petrological support.

Possibility 2 is our main concern in this paper. As we mentioned already, not all the subduction boundaries have backarc basins, and not all subduction boundaries that have backarc basins are presently actively opening. We will first classify the subduction boundaries by back-arc type and then demonstrate that the differences in back-arc type correlate with other phenomena which are presumed to be related to the tectonic stress state. We will next dicuss the possibility that the difference in the tectonic stress state in back-arc regions may be caused by a difference in the mode of subduction and attempt to find out why such different modes of subduction occur.

\section{Classification of Subduction Boundaries}

Karig [1971b] classified marginal basins into active marginal basins (type 1), inactive marginal basins with high heat flow (type 2), and inactive marginal basins with normal heat flow (type 3 ). He postulated that types 2 and 3 were active in the past, type 2 in the more recent past than type 3 . We use ideas more or less similar to Karig's to classify the subduction boundaries in Table 1. First, subduction boundaries (trencharc-back-arc systems) are grouped into the continental arcs and island arcs. Continental arcs, by definition, have no backarc basins. The back-arc area of the Sumatra and Java arc is 
TABLE 1. Classification of Trench-Arc-Back-Arc Systems

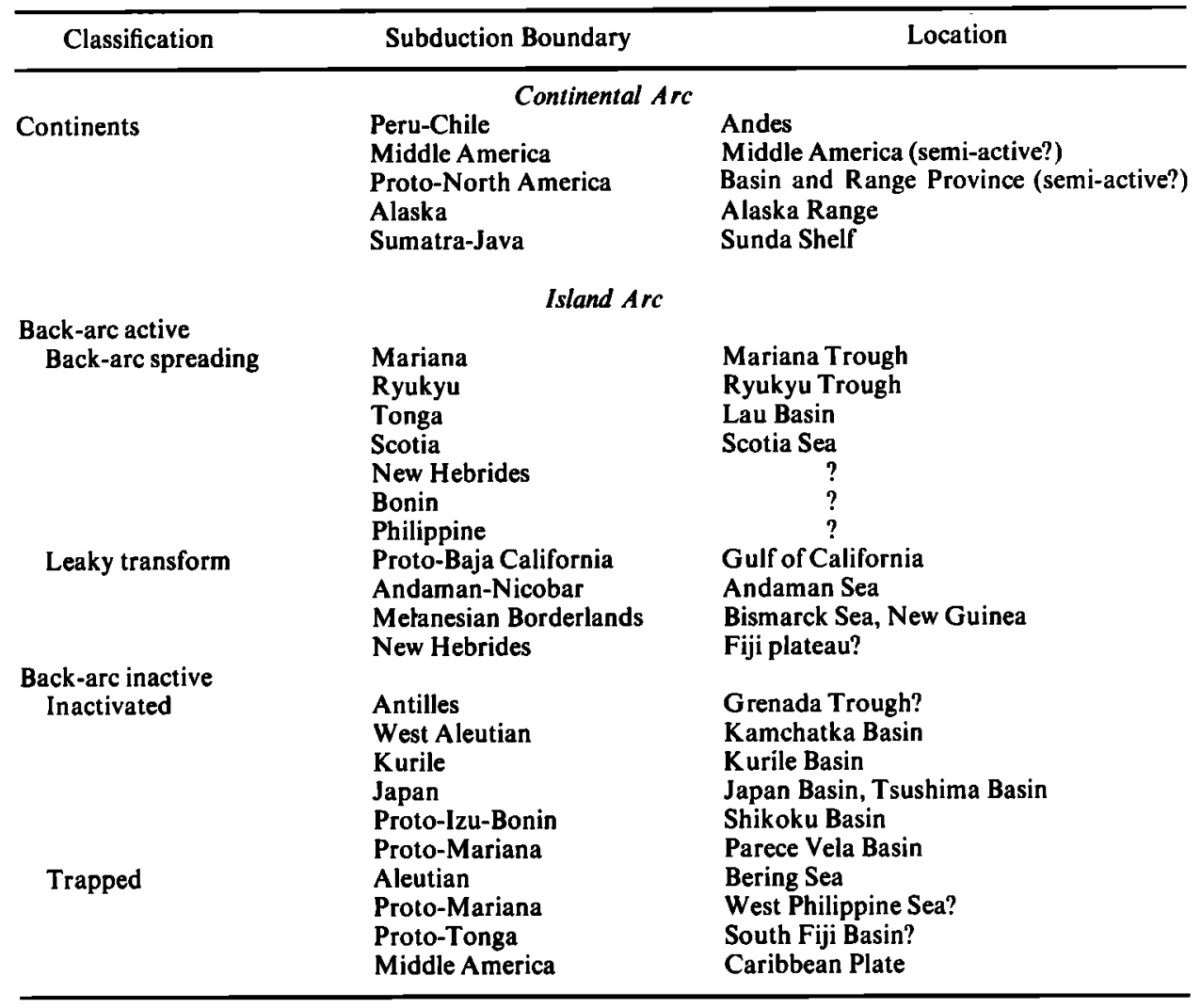

water covered, but this arc is grouped with the continental arcs because most of the back-arc area has only shallow water depth (about $100 \mathrm{~m}$ ) and presumably a continental crust. Conversely, the Middle American arc, though included in the continental arcs, might be better grouped with the back-arc spreading type because of the extensional volcanic grabens found in Middle America [Plafker, 1976]. A similar argument may hold for the Proto-North American arc, which is sup-

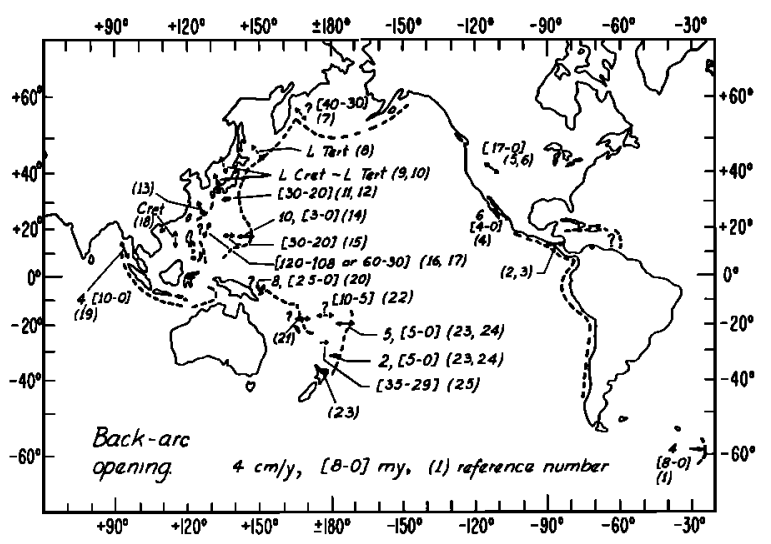

Fig. 1. Summary of back-arc opening activities. Reference numbers are as follows: 1, Barker and Griffiths [1972]; 2, Malfait and Dinkelman [1972]; 3, Plafker [1976]; 4, Larson [1972]; 5, Scholz et al. [1971]; 6, Christiansen and Lipman [1972], Smith [1977]; 7, Cormier [1975]; 8, Beloussov [1968]; 9, Hilde and Wageman [19731;-10, Uyeda and Miyashiro [1974]; 11. Tomoda et al. [1975]; 12, Watts and Weissel [1975]; 13, Herman et al. [1979]; 14, Karig [1971a]; 15, Heezen et al. [1971]; 16, Louden [1976]; 17, Shih [1978]; 18, Ben-Avraham and Uyeda [1973]; 19, Curray et al., [1979]; 20, Connelly [1976]; 21, Karig and Mammerickx [1972]; 22, Chase [1971]; 23, Karig [1970]; 24, Karig [1971b]; and 25, Weissel and Watts [1975]. posed to have existed before the collision of the East Pacific Rise with the North American continent [McKenzie and Morgan, 1969; Scholz et al., 1971]. Island arcs are classified into those with active back-arc basins and those with inactive backarc basins. Active and inactive refer to whether the opening of the basin is presently in progress or not. A back-arc basin which has rift topography and/or fault structure suggestive of tensional tectonics is considered to be actively opening if it shows one or more of the following characteristics: (1) thin sediment cover of very young age over rugged volcanic basement relief, (2) shallow water depth comparable to that of active midoceanic ridges, (3) high heat flow or highly variable heat flow [Watanabe et al., 1977], or (4) magnetic lineations with zero age.

The actual classification in Table 1 was made using the references indicated in the legend of Figure 1. Figure 1 summarizes this information regarding the time and rate of opening.

Typical examples of the actively spreading back-arc basins are the Mariana Trough and the Lau Basin. Among those that are supposed to be actively spreading, magnetic lineations of very young age have been documented for the Scotia Sea. On the whole, the magnetic lineations in the back-arc basins are much less well developed than those in oceans [Watts and Weissel, 1975; Weissel and Watts, 1975; Kobayashi and Isezaki, 1977; Lawver and Hawkins, 1978], suggesting that either the mode of spreading in the two cases is different or the back-arc spreading corresponds to the very early stage of oceanic spreading.

The Fiji Plateau, behind the New Hebrides arc, satisfies the above criteria for an active back-arc basin, but there the polarity of the subduction is anomalous; polarity reversal occurred in the late Miocene (10 m.y. B.P.), when the Ontong Java Plateau collided with the now extinct trench [Chase, 1971; 


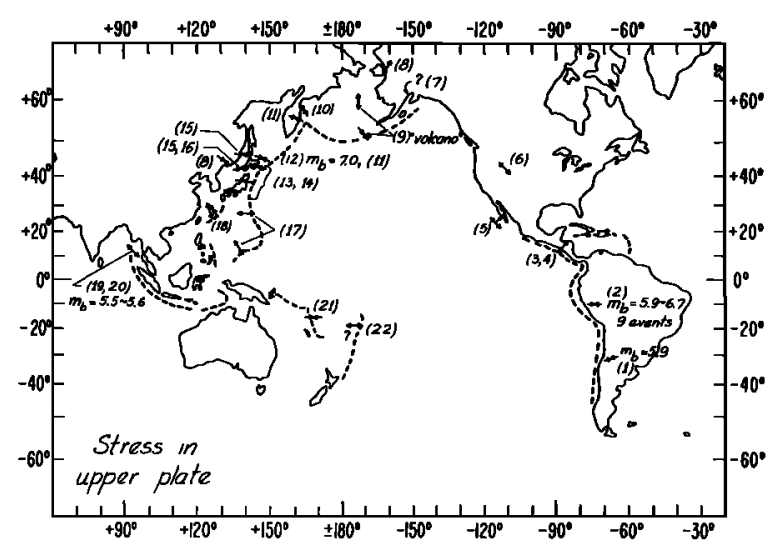

Fig. 2. Stress state estimated from source mechanism of intraplate earthquakes in back-arc regions; $m_{b}$ is magnitude. Reference numbers are as follows: 1, Stauder [1973]; 2, Stauder [1975]; 3, Molnar and Sykes [1969]; 4, Matumoto and Latham [1976]; 5, Sykes [1968]: 6, Scholz et al. [1971]; 7, Gedney [1970]; 8, Sykes and Sbar [1974]; 9, Nakamura et al. [1977]; 10, Cormier [1975]; 11, Veith [1974]; 12, Stauder and Mualchin [1976]; 13, Honda et al. [1967]; 14, Ichikawa [1969]; 15, Fukao and Furumoto [1975]; 15, Averyanova [1973]: 17, Katsumata and Sykes [1969]; 18, Fitch [1972]; 19, Fitch [1970]: 20. Eguchi et al. [1979]; 21, Chung and Kanamori [1978]; and 22, Hawkins [1974].

Karig and Mammerickx, 1972]. Conflciting ideas have been proposed for the active back-arc spreading in the belt immediately behind the New Hebrides arc [Karig and Mammerickx, 1972; Luyendyk et al., 1974].

The entire length from Fiji to New Guinea, called the Melanesia Borderland, forms the complex megashear boundary between the two large Pacific and India-Australia plates. The Bismarck Sea is said to be spreading [Connelly, 1976] but is regarded as atypical [Coleman and Packham, 1976], due to the reversely polarized Solomon Trench. The Gulf of California and Andaman Sea are also located on megashear boundaries between two large plates and are actively opening by the leaky transform fault mode. In both cases, some magnetic lineations with young ages have been reported [Larson, 1972; Curray et al., 1979]. Common to both cases are the collision of a ridge and a trench in the recent geologic time (Miocene) [Atwater. 1970; Eguchi et al., 1979]. The Gulf of California is not a backarc at present, but it was so in the past until the time of the ridge-trench collision. The Basin and Range Province may be similar in some ways [Thompson and Burke, 1974; Scholz et al., 1971; Smith, 1977]. Thus, it now seems that active back-arc basins may be classified as a subduction-related type or a leaky transform type.

The Middle American arc is classified as having a trapped back-arc also because it has a large area of back-arc basin, the Caribbean. The present Caribbean Sea in the model of Malfait and Dinkelman [1972] was a part of the Pacific Ocean during the Late Cretaceous to early Oligocene, just as the present Scotia Sea is, and was trapped by the emergence of the Middle America arc in the early Oligocene time. Portions of the Caribbean Sea may instead be regarded as a back-arc basin of the Antilles arc. Probably, the present Grenada Basin was produced by spreading behind the Antilles arc in the past, but whether it is actively spreading at present has not been ascertained. Thus, the Antilles arc is classified as having an inactivated back-arc. The West Philippine Basin [Uyeda and BenAvraham, 1972] and the South Fiji Basin [Hilde et al., 1977] may also be the trapped type, but this is highly conjectural.
Typical of the 'inactivated' back-arc basins are the Japan, Kurile, Shikoku, and Parece Vela Basins. Those basins are supposed to have been actively spreading in the recent past but do not appear to be active any more. It is important to note that some of these inactivated back-arc basins are still associated with active subduction boundaries. This applies also to the Bering Sea.

\section{Stress State in Back-Arc Plate}

It seems natural to conjecture that the tectonic stress in the upper plate at a subduction boundary may be dominantly compressional because two plates are converging at the boundary. In fact, earthquake source mechanisms, geodetic observations, and faults and folds [Sugimura and Uyeda, 1973] suggest that the stresses in the Japanese islands are generally compressional in the direction of the plate convergence. It seems, however, that the upper layer of the upper plate must be under a tensional stress regime for the back-arc basin to spread. Thus, all the models so far proposed to explain the spreading in back-arc basins were devised to generate a tensional stress field in the upper part of the upper plate at a converging plate boundary [Karig, 1971b; McKenzie, 1969; Hasebe et al., 1970; Sleep and Toksoz, 1971; Sleep, 1975]. In this paper, we concentrate on the fact that some subduction boundaries have an active back-arc and others do not and attempt to find a clue to the problem of the origin of back-arc spreading by clarifying the differences in these two types of subduction boundaries. For this purpose, we first investigate whether these two types of back-arcs are indeed under different stress conditions using published source mechanism solutions of shallow earthquakes occurring in the upper plates.

At the earlier stage of plate tectonics, mainly interplate earthquakes were intensively investigated to determine the relative plate motions. More recently, the mechanisms of intraplate earthquakes have been studied to determine the stress states in the plates, which bear directly on the driving mechanism of plate motions [Mendiguren, 1971; Forsyth, 1973; Sykes and Sbar, 1973, 1974; Richardson et al., 1976].

Unfortunately, few mechanism solutions are available for use in this paper because intraplate earthquakes (especially with magnitude large enough to be recorded at a sufficiently large number of stations) are very much fewer than those at plate boundaries, and initial interest in the intraplate stress has

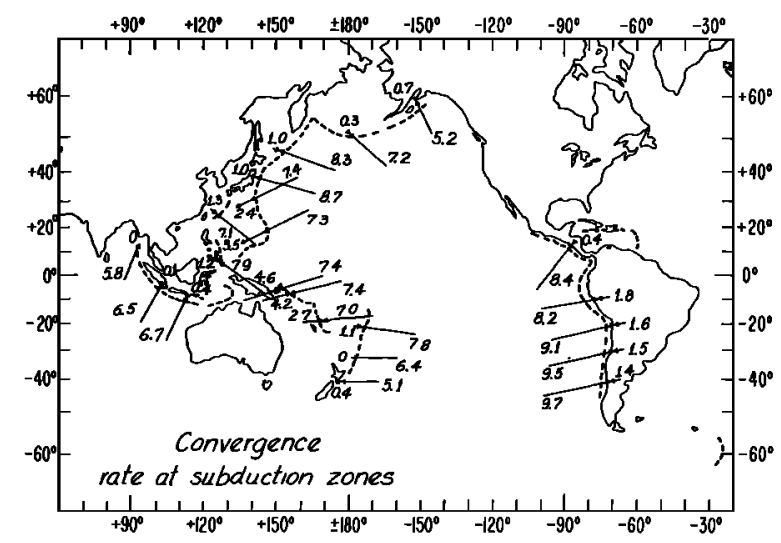

Fig. 3. Convergence rates at subduction boundaries in centimeters per year (after AM1 of Minster et al. [1974] and Fitch [1972]). Arrows indicate the component of the absolute velocity vector of each plate in the direction of plate convergence. 
been concentrated on the central portions of plates rather than on peripheral areas.

A compilation of the published results of the few available source mechanism solutions is shown in Figure 2. In the Chilean and Peruvian arcs, the mechanisms of upper plate shallow earthquakes obtained by Stauder [1973, 1975] are mostly thrust and strike slip, but the direction of the compressional stress in both cases is perpendicular to the strike of the arc (Figure 2). The situation is the same for the Kurile and Japan arcs, which have inactivated back-arcs. On the other hand, upper plate shallow earthquakes in the typically active backarc basins, such as Mariana Trough, Lau Basin, and Andaman Sea, and in similar types of regions, such as the Gulf of California, the Basin and Range Province, and Middle America, show normal faulting. Here again, there are strike slip earthquakes in these regions, but the directions of compression and tension are consistent with those inferred from the normal fault events. Immediately behind the New Hebrides arc, the one available solution is a reverse fault [Chung and Kanamori, 1978] and argues against the active opening of this area. In view of general evidence for extensional features in the backarc region [Dugas et al., 1977], the New Hebrides arc is an enigma for us at this moment. The stress arrows immediately behind the Aleutians and in the middle of the Bering Sea are estimates, based on the distribution of flank eruptions, which can be considered as natural hydrofractures [Nakamura et al., 1977]. The stress is compressional in the immediate back-arc, as expected for an inactive back-arc, but that in the Bering Sea is tensional. A tensional earthquake mechanism was reported in the western tip of Alaska [Sykes and Sbar, 1974]. This may mean that the compressive stress in the volcanic arc is not transmitted several hundred kilometers inward, or there is an intrinsic mechanism that generates a tensional tectonic stress regime behind the arcs [Scholz et al., 1971; K. Nakamura, private communication, 1977]. Although the amount of information is small and there are arcs, like the Scotia and Sunda arcs, where no information is available, it appears that tensional and compressional stress regimes dominate in the active and inactive back-arc regions, respectively. In the following, we will call these two types of back-arc regions 'Mariana' type and 'Chilean' type for simplicity.

\section{INTERPLATE EARTHQUAKES AND MODE OF SUbDuction}

Why are there different stress regimes behind subduction boundaries? Could this difference be caused by some important difference in the subduction process itself? Interplate thrust type earthquakes, that are caused by interaction between the subducting and overthrusting plates, should provide pertinent information on this point. As is well known, a majority of the earthquakes that occur are interplate thrust events at subduction boundaries. An examination of world seismicity maps [e.g., Barazangi and Dorman, 1969, Tarr, 1974] shows that epicenters are more or less evenly distributed along subduction boundaries. No systematic difference is obvious between the Mariana and Chilean type boundaries. The same is true for the convergence rate at the boundaries (Figure 3): Although the convergence rate seems higher at Chilean type boundaries than at Mariana type ones, the distinction is not completely clear.

The distinction is, however, very clear in the rate of earthquake energy release. To demonstrate this, we use the seismic energy released in great earthquakes. The conventional earthquake magnitude, $M$, [Gutenberg and Richter, 1954] suffers saturation for great earthquakes $(M>7.5)$ and becomes un-
TABLE 2. Ten Greatest Earthquakes During 1904-1976

\begin{tabular}{llllc}
\hline Earthquake & Year & $\boldsymbol{M}_{\boldsymbol{s}}$ & $\boldsymbol{M}_{\boldsymbol{w}}$ & $W_{0}$ \\
\hline Chile & 1960 & 8.3 & 9.5 & $1.1 \times 10^{28}$ \\
Alaska & 1964 & 8.4 & 9.2 & $4.0 \times 10^{25}$ \\
Aleutian Islands & 1957 & 8.25 & 9.1 & $2.8 \times 10^{25}$ \\
Kamchatka & 1952 & 8.25 & 9.0 & $2.0 \times 10^{25}$ \\
Ecuador & 1906 & 8.6 & 8.8 & $1.0 \times 10^{25}$ \\
Aleutian Islands & 1965 & 7.75 & 8.7 & $7.1 \times 10^{24}$ \\
Assam & 1950 & 8.6 & 8.6 & $5.0 \times 10^{24}$ \\
Kurile Islands & 1963 & 8.1 & 8.5 & $3.5 \times 10^{24}$ \\
Chile & 1922 & 8.3 & 8.5 & $3.5 \times 10^{24}$ \\
Banda Sea & 1938 & 8.2 & 8.5 & $3.5 \times 10^{24}$ \\
\hline
\end{tabular}

suitable as the meaningful scale of the size of earthquakes. This happens when the size of the rupture surface becomes comparable or larger than the wavelength of the seismic wave used for $M$ determination. For such a great earthquake, since more energy is released by lower-frequency waves, the 'energy' meaningful to tectonics may better be estimated from static source parameters such as seismic moment. Kanamori [1977a] used this approach for the world's great earthquakes since 1904. The seismic moment $\left(M_{0}=\mu \overline{D S}\right.$, where $\mu$ is rigidity, $\bar{D}$ is average displacement on the fault, and $S$ is fault area) was evaluated for each great earthquake from long-period body wave, surface wave, free oscillation, and geodetic data, and the energy release $W_{0}$ was obtained by

$$
W_{0}=(\Delta \sigma / 2 \mu) M_{0}
$$

where $\Delta \sigma$ is the stress drop. $W_{0}$ is considered to be a good estimate of the energy released in seismic waves. Using $W_{0}$, a new magnitude $M_{w}$, which is meaningful even in the range $M \gtrsim 8.0$, was calculated using Gutenberg and Richter's formula:

$$
\log W_{0}=1.5 M_{w}+11.8
$$

Table 2 (from Table 2 of Kanamori [1977a]) lists the 10 largest earthquakes that occurred between 1904 and 1976. Two points should be noted: (1) These 10 large earthquakes released more than $90 \%$ of the world's total seismic wave energy released during 1904-1976, and (2) none of these really great earthquakes occurred at the Mariana type boundaries. This is true for the 40 largest earthquakes listed by Kanamori [1977a], which cover more than $95 \%$ of the total seismic energy (see Figure 4). Although there are a few great earthquakes in the Assam and Mongolia areas, all the truly great thrust interplate earthquakes occur exclusively at the Chilean type subduction boundaries. At the Mariana type boundaries, subduction must be going on essentially aseismically if the convergence rate shown in Figure 3 represents the present-day motion [Kanamori, 1977b]. Figure 4 shows that Chilean type boundaries have great earthquakes.

Thus, in general, at a Chilean type margin the slab appears to force itself into the mantle overcoming the strong resistive interaction with the upper plate, whereas in the Mariana type margin the slab falls into the mantle relatively freely. The gradation from the former to the latter may be observed in Figure $\mathbf{4}$ from Alaska to the Marianas via the Kurile, Japan, and Izu-Bonin arcs.

\section{Other Phenomena Possibly Related to the Two Modes of Subduction}

The differences in the mode of subduction suggested in the previous section have other possible consequences. We will 


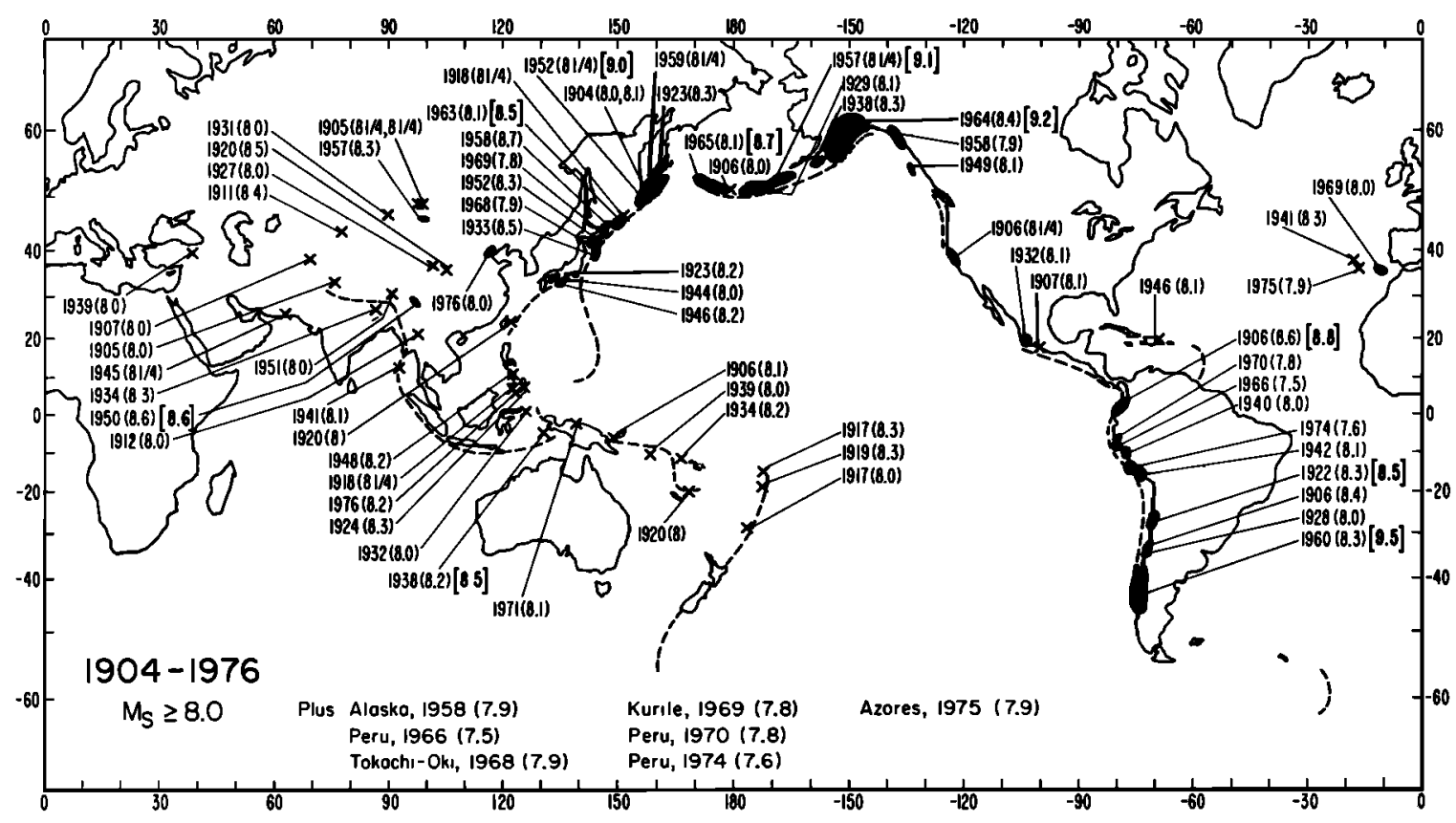

Fig. 4. Great earthquakes during 1904-1976 [after Kanamori, 1978]. Conventional magnitudes are in parentheses, and new magnitudes are in brackets. Black areas are rupture zones.

examine some of them in this section. They are, in our view, promising but need further elaboration to be conclusive.

\section{Outer Gravity High and Outer \\ Topographic Rise}

It is well known that often there exist a positive gravity anomaly belt and topographic rise just outside of trenches. Hanks [1971] and Watts and Talwani [1974] interpreted these features as a result of the oceanic plate being compressed horizontally before subduction. One feature to be noted is that both gravity and topographic highs are wide and prominent off the Aleutian and Kurile trenches but become gradually less wide and less prominent toward the south from the Japan trench to the Marianas trench [Watts and Talwani, 1974, Figure 1]. The previously noted similarity [Kanamori, 1977b] to the trend of diminishing great earthquakes is interesting. Outer gravity highs around the circum-Pacific region are summarized in Table 3 and Figure 5 [Getts, 1975; Watts et al., 1976]. Figure

TABLE 3. Outer Gravity High

\begin{tabular}{|c|c|c|c|c|}
\hline Trench & References* & Outer Gravity High & $\Delta \mathrm{g}, \mathrm{mGal}$ & Width, $\mathrm{km}$ \\
\hline $\begin{array}{l}\text { Peru-Chile } \\
\text { Middle America }\end{array}$ & $\begin{array}{l}1,2 \\
1\end{array}$ & $\begin{array}{l}\quad \text { Continental Arc } \\
\text { Well developed south of } 18^{\circ} \mathrm{S} \\
\text { Exists but not well defined }\end{array}$ & $40-60$ & $300-400$ \\
\hline Alaska & 1,3 & Well developed & 50 & 600 \\
\hline Sumatra-Java & 1 & Well developed & 50 & 200 \\
\hline Nankai & 1 & Not clear & $\cdots$ & $\cdots$ \\
\hline Aleutian & 1,3 & $\begin{array}{l}\text { Trapped Back-Arc } \\
\text { Well developed }\end{array}$ & $50-60$ & $350-500$ \\
\hline $\begin{array}{l}\text { Kurile } \\
\text { Japan }\end{array}$ & $\begin{array}{l}1,3,4 \\
1,3\end{array}$ & $\begin{array}{l}\text { Inactivated Back-Arc } \\
\text { Well developed } \\
\text { Well developed }\end{array}$ & $\begin{array}{l}40 \\
30\end{array}$ & $\begin{array}{l}300-400 \\
300\end{array}$ \\
\hline Andaman-Nicobar & 1 & $\begin{array}{l}\text { Leaky Transform } \\
\text { Not developed }\end{array}$ & $\cdots$ & $\cdots$ \\
\hline $\begin{array}{l}\text { Mariana } \\
\text { Tonga } \\
\text { Kermadec } \\
\text { Ryukyu }\end{array}$ & $\begin{array}{l}1,3 \\
1,3 \\
1,3 \\
1,3\end{array}$ & $\begin{array}{l}\quad \text { Back-Arc Spreading } \\
\text { Not developed } \\
\text { Not developed north of } 24^{\circ} \mathrm{S} \\
\text { Developed } \\
\text { Not developed }\end{array}$ & $\begin{array}{l}40-20 \\
-30\end{array}$ & $\begin{array}{l}70 \\
100\end{array}$ \\
\hline Bonin & 1,3 & $\begin{array}{l}\text { Unidentified } \\
\text { North, developed; south, not } \\
\text { developed }\end{array}$ & 40 & 150 \\
\hline Philippine & 1,3 & Well developed & 60 & 400 \\
\hline
\end{tabular}

*References are 1, Watts and Talwani [1974]; 2, Getts [1975]; 3, Watts et al. [1976]; and 4, Hanks [1971]. 


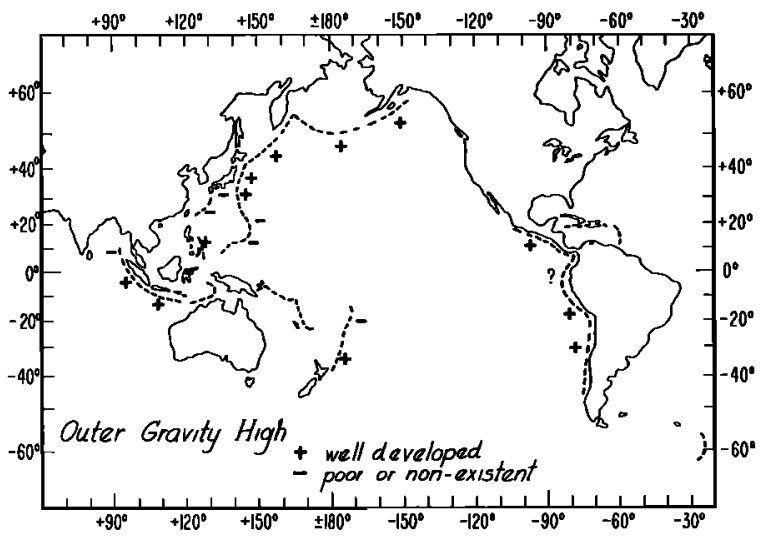

Fig. 5. Distribution of trench outer gravity high [after Watts and Talwani, 1974; Getts, 1975; Watts et al., 1976].

5 shows substantial correspondence with the two modes of subduction.

We realize that there are problems in both observations and models of the outer gravity and topographic highs [e.g., Caldwell et al., 1976]. Therefore, although the first-order effect may be meaningful, final conclusions must await further investigation.

\section{Dip of Benioff-Wadati Zones}

The dip of Benioff-Wadati zones may be shallower for the Chilean type subduction than for the Mariana type subduction. Simplified Benioff-Wadati zones from various sources including Isacks and Barazangi [1977], are shown in Table 4 and Figure 6, in which mainly features deeper than $100 \mathrm{~km}$ are represented. When the Benioff-Wadati zone is shallow, as in the case of the Andaman-Nicobar, Middle America, Aleu- tians, Alaska, and Lesser Antilles, features shallower than 100 $\mathrm{km}$ are shown, but the problems related to the shallower features [Karig et al., 1976] will be touched upon later. Figure 6 testifies that the dip of the Benioff-Wadati zone is definitely shallow for the Peru-Chile arc and Sumatra arc and deep for the Mariana, Kermadec, and Scotia (not well constrained) arcs. Here again, the grouping typified by the Chilean and Mariana arcs seems to hold.

Some arcs, that are considered to have inactive back-arcs, also have steep Benioff-Wadati zones: for example, Java, New Britain, Philippine, Solomon and possibly New Hebrides arcs. However, these Benioff-Wadati zones tend to be discontinuous in the direction of dip as indicated by broken lines in Figure 6. This may mean that the downgoing slab is disrupted in these subduction zones.

\section{Nature of Volcanism}

The compositions of volcanic rocks are different for different tectonic settings [Miyashiro, 1975]. Generally speaking, the representative volcanics are midoceanic ridge type tholeiites at diverging boundaries, alkali basalts and tholeiites in midplate volcanism, and andesites in addition to tholeiites at converging boundaries. The origin of andesite itself is one of the major problems in igneous petrology, but here we attempt to compare the abundance of andesites for different subduction boundaries. The reason for such a comparison is that, for example, in western North America, andesitic volcanism was dominant in early Tertiary, when the west coast of North America was a subduction boundary; the volcanism changed to the basalt-rhyolite type after the collision of the PacificFarallon ridge with the then existing trench [Dickinson, 1970].

Scholz et al. [1971] suggested that the stress field changed from compressional to tensional in western North America

TABLE 4. Dip of Benioff-Wadati Zones

\begin{tabular}{|c|c|c|c|c|c|}
\hline Arc & $\begin{array}{l}\text { Approximate } \\
\text { Position of Plate } \\
\text { Boundary, deg }\end{array}$ & $\begin{array}{c}\text { Strike of } \\
\text { Section, deg }\end{array}$ & $\begin{array}{l}\text { Maximum } \\
\text { Depth, km }\end{array}$ & Dip, deg & References \\
\hline Scotia & $58^{\circ} \mathrm{S}, 24^{\circ} \mathrm{W}$ & EW & 180 & 70 & $\begin{array}{l}\text { E. R. Engdahl, personal communication } \\
(1977)\end{array}$ \\
\hline South Chile & $40^{\circ} \mathrm{S}, 72^{\circ} \mathrm{W}$ & $\mathrm{N} 100^{\circ} \mathrm{E}$ & 160 & 30 & Isacks and Barazangi [1977] \\
\hline Central Chile & $30^{\circ} \mathrm{S}, 70^{\circ} \mathrm{W}$ & $\mathrm{N} 100^{\circ} \mathrm{E}$ & 150 & 11 & Isacks and Barazangi [1977] \\
\hline North Chile & $20^{\circ} \mathrm{S}, 70^{\circ} \mathrm{W}$ & $\mathrm{N} 70^{\circ} \mathrm{E}$ & 290 & 30 & Isacks and Barazangi [1977] \\
\hline Peru & $10^{\circ} \mathrm{S}, 78^{\circ} \mathrm{W}$ & $\mathrm{N} 60^{\circ} \mathrm{E}$ & 150 & 8 & Isacks and Barazangi [1977] \\
\hline Middle America & $12^{\circ} \mathrm{N}, 87^{\circ} \mathrm{W}$ & $\mathrm{N} 45^{\circ} \mathrm{E}$ & 200 & 65 & Dewey and Algermissen [1974] \\
\hline Lesser Antilles & $15^{\circ} \mathrm{N}, 60^{\circ} \mathrm{W}$ & EW & 230 & 65 & Sykes and Ewing [1965] \\
\hline Alaska & $59.5^{\circ} \mathrm{N}, 150^{\circ} \mathrm{W}$ & $\mathrm{N} 73^{\circ} \mathrm{W}$ & 150 & 55 & Lahr [1975] \\
\hline Central Aleutians & $51^{\circ} \mathrm{N}, 180^{\circ} \mathrm{E}$ & NS & 260 & 65 & Engdahl et al. [1977] \\
\hline Kuriles & $45^{\circ} \mathrm{N}, 153^{\circ} \mathrm{E}$ & $\mathrm{N} 40^{\circ} \mathrm{W}$ & 650 & 50 & Engdahl et al. [1977] \\
\hline Northeast Japan & $40^{\circ} \mathrm{N}, 144^{\circ} \mathrm{E}$ & EW & 600 & 40 & Ishida $[1970]$ \\
\hline Ryukyu & $24^{\circ} \mathrm{N}, 126^{\circ} \mathrm{E}$ & $\mathrm{N} 30^{\circ} \mathrm{W}$ & 300 & 45 & Katsumata and Sykes [1969] \\
\hline Philippine (Mindanao) & $5^{\circ} \mathrm{N}, 128^{\circ} \mathrm{E}$ & EW & 600 & 55 & Hamilton [1974] \\
\hline Izu-Bonin & $30^{\circ} \mathrm{N}, 143^{\circ} \mathrm{E}$ & $\mathrm{N} 100^{\circ} \mathrm{W}$ & 500 & 65 & Katsumata and Sykes [1969] \\
\hline Marianas & $18^{\circ} \mathrm{N}, 148^{\circ} \mathrm{E}$ & EW & 700 & 90 & Katsumato and Sykes [1969] \\
\hline Tonga & $21^{\circ} \mathrm{S}, 173^{\circ} \mathrm{W}$ & $\mathrm{N} 70^{\circ} \mathrm{W}$ & 650 & 53 & Isacks and Barazangi [1977] \\
\hline Kermadec & $33^{\circ} \mathrm{S}, 178^{\circ} \mathrm{W}$ & $\mathrm{N} 70^{\circ} \mathrm{W}$ & 550 & 65 & Isacks and Barazangi [1977] \\
\hline New Zealand & $40.5^{\circ} \mathrm{S}, 177^{\circ} \mathrm{E}$ & $\mathrm{N} 48^{\circ} \mathrm{W}$ & 300 & 67 & Ansell and Smith [1975] \\
\hline New Hebrides & $17^{\circ} \mathrm{S}, 167^{\circ} \mathrm{E}$ & $\mathrm{N} 70^{\circ} \mathrm{E}$ & 300,530 & 70 & $\begin{array}{l}\text { Isacks and Barazangi [1977] } \\
\text { Dubois [1971] }\end{array}$ \\
\hline New Britain & $6^{\circ} \mathrm{S}, 147^{\circ} \mathrm{E}$ & $\mathrm{N} 40^{\circ} \mathrm{W}$ & 200,600 & 65 & Isacks and Molnar [1971] \\
\hline Solomons & $6^{\circ} \mathrm{S}, 154^{\circ} \mathrm{E}$ & $\mathrm{N} 40^{\circ} \mathrm{E}$ & $\begin{array}{l}150 ; 550 \text { in } \\
\text { northwest corner }\end{array}$ & 70 & Isacks and Molnar [1971] \\
\hline Andaman & $12^{\circ} \mathrm{N}, 92^{\circ} \mathrm{E}$ & EW & 100 & 50 & Eguchi et al. [1979] \\
\hline Sumatra & $5^{\circ} \mathrm{S}, 100^{\circ} \mathrm{E}$ & $\mathrm{N} 60^{\circ} \mathrm{E}$ & 200 & 30 & Fitch $[1970]$ \\
\hline Java & $10^{\circ} \mathrm{S}, 113^{\circ} \mathrm{E}$ & NS & 300,600 & 55 & Fitch $[1970]$ \\
\hline Banda Sea & $7^{\circ} \mathrm{S}, 130^{\circ} \mathrm{E}$ & $\mathrm{N} 30^{\circ} \mathrm{W}$ & 400 & 55 & Fitch [1970] \\
\hline
\end{tabular}




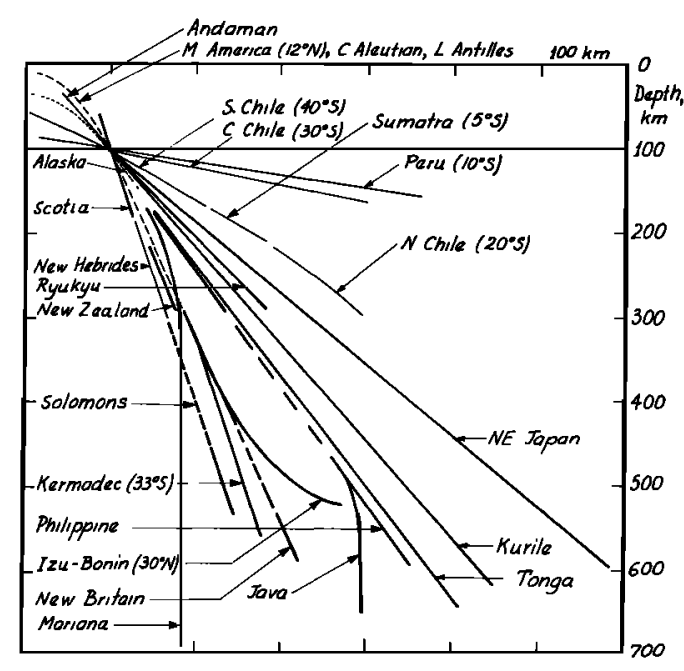

Fig. 6. Dip of Benioff-Wadati zones (after the references listed in Table 4).

when the Pacific-Farallon ridge collided with the subduction zone. The change in the nature of volcanism may be explained as follows (K. Nakamura, personal communication, 1977): The parental basaltic magmas can ascend and erupt more easily in a tensional stress field than in a compressional environment. In the latter situation, the magma, while forcing its way to the surface, tends to stay. longer in the crust and is more prone to react with the surrounding rocks to produce andesitic rocks.

According to the synthesis of Miyashiro [1975], andesites are abundant in continental arcs and mature island arcs (island arcs with substantial continental crust, e.g., Japan), and rare in immature island arcs (island arcs without continental crust, e.g., the Marianas). Here we note that these correspond with our Chilean type and Mariana type arcs. This seems to suggest that the mode of development of arcs may also be controlled by the mode of subduction. In the Mariana type subduction boundaries, back-arc spreading will soon start to break the arc longitudinally [Karig, 1972], so that the arc becomes thin and pushed away from the continent, the source of terrigeneous sediments, inhibiting the rapid growth of the accretionary prism (discussed later).

Sugisaki $[1972,1976]$ demonstrated that the abundance of andesite is controlled by the convergence rate: andesite is more abundant where the convergence rate is high. However, in his observation, the Tonga and Izu-Mariana arcs constitute notable exceptions where the convergence rate is high and andesite is scarce. Sugisaki's observation seems to be better explained by our interpretation.

Further, according to Nakamura et al. [1977], the structure of volcanoes is also dependent on the tectonic stress: large stratovolanic edifices grow in the Chilean type environment, whereas small many monogenic volcanoes are found in the tensional environment. The series of monogenic cones in the Middle America arc are examples of the latter. Again, the difference is caused by the general ease of magma eruption under a tensional regime. These observations appear to confirm our notion of the two types of subduction, but certainly more thorough investigation is needed.

\section{Sedimentary Structure on the Landward Wall of Trenches}

It is now believed that an accretionary prism of sediments develops on the landward wall of trenches. The sediments are probably of terrigenous origin or are scraped off pelagic sediments from the oceanic plate. The prism rises due to the compression and sometimes emerges above sea level to form the so-called outer arc such as Mentawasi Island off Sumatra and Middleton Island off the Aleutian Arc. Landward of the outer arc, sedimentary basins called deep sea terraces or forearc basins often develop. The development of those structures is controlled by various factors such as the supply of terrigenous material, the duration of subduction, and the history before the onset of subduction. Thus one would expect that the regional difference in the mode of subduction significantly affects the structure of the accretionary prism. In fact, the growth of accretionary prism appears more pronounced in our Chilean type boundaries than Mariana type ones [Karig and Sharman, 1975, Figure 5]. Often, one encounters exposures of basement in the wall of the latter type trenches. As a result of the growth of the sedimentary structure, the oceanic plate tends to be bent downward by the sediment load and thus creates the long shallow dipping slope at a shallow part (depth of $<30 \mathrm{~km}$ ) of the Benioff-Wadati zone [Karig et al., 1976]. Karig and Sharman [1975] attribute the difference in the growth of fore-arc sedimentary structures to that of the sediment supply (supply rate times duration). Here we suggest that the difference in the mode of subduction may be an additional factor which gives rise to the difference in the structure of the accretionary prism. In the Chilean type boundaries, the strong mechanical coupling causes an extensive contortion and development of the accretionary prism, whereas in the Mariana type boundaries, because of the relatively weak coupling, subduction takes place without strong resistance from the upper plate, resulting in less contorted, or lack of, accretionary prisms. However, more detailed interpretation must await further investigations on the origin of the sediments that form the accretionary prism. The difference in the supply itself would, to a certain degree, ultimately be caused by the difference in the subduction mode as mentioned earlier, because the Mariana type arcs always tend to be at some distance from the continent.

As stated above, the outer arcs or frontal arcs are probably the raised sediments. Such a rise would have the same mechanism as that of the coastal uplifts estimated from coastal terraces and the actual coastal uplifts associated with major thrust earthquakes [Yonekura, 1975]. Such uplifts are also expected to be much more evident at the Chilean type subduction boundaries than the Mariana type. Although further investigations are required, preliminary literature surveys indicate that Quaternary coastal uplifts are prominent in Japan, Taiwan, Indonesia, western South America, Alaska, New Guinea, and New Hebrides [Ota and Naruse, 1977].

Although terraces are observed in Mariana and Tonga, the rate of uplift appears to be almost an order of magnitude smaller than in the Chilean type coasts [Taylor and Bloom, 1977; N. Yonekura, personal communication, 1978].

\section{Possible Models of the Two Modes of Subduction}

Summarizing the argument developed in the previous sections, there are two different modes of subduction. The extreme cases of each mode are represented by the Chilean arc and Mariana arc. At the Chilean type subduction boundaries, the mechanical coupling between the upper and lower plates is strong, whereas at the Mariana type boundaries the coupling is either much weaker or effectively nonexistent. The two types 


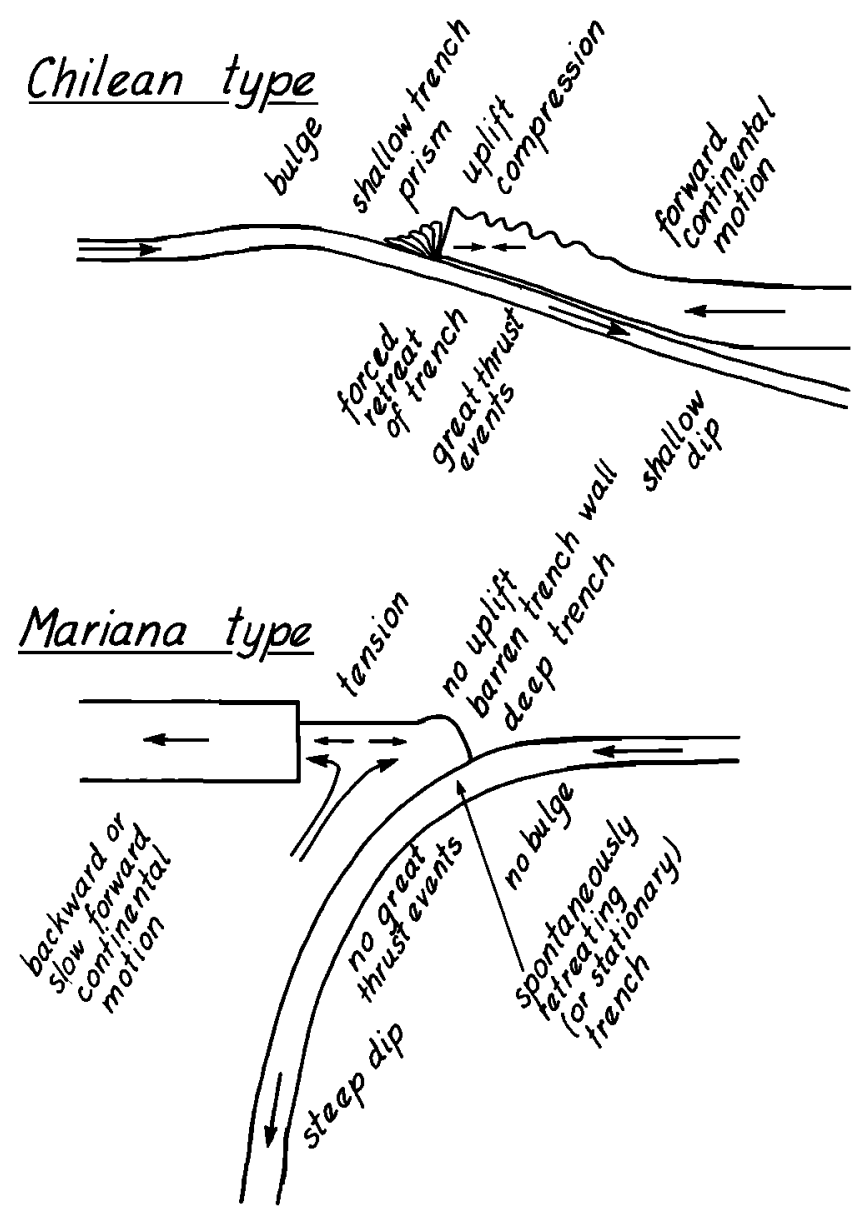

Fig. 7. Two kinds of subduction boundaries.

may be illustrated as shown in Figure 7. The difference in the subduction mode seems to be important not only for the problem of back-arc spreading but also for more general problems of orogeny.

\section{Evolutionary Model}

This model views the different modes of subduction as representing the different stages of a single evolutionary process of subduction [Kanamori, 1971a, 1977b]. As seen in Figure 8, the process of subduction starts with low-angle thrusting as in the case of the Alaska Trench. Here a wide contact zone between the upper and lower plates provides a strong coupling between the two plates, and great earthquakes occur at the interface. This is the mode that we call in this paper the Chilean type and that we regard as the first stage of subduction (Figure $8 a$ ). As the process goes on, the oceanic plate subducts to a greater depth in the mantle, and the contact interface is heavily fractured by repeating fault movements. This repeated fracturing may result in reduced coupling of the two plates through various processes such as formation of fault gouge, increased pore pressure, and possible partial melting. This may be the state of the Kurile arc (Figure $8 b$ ). If the process continues, the upper and lower plates will be almost completely decoupled so that there will be no more great earthquakes. The elongated tongue of the high-density slab will exert strong tension in the upper part of the slab to cause great normal fault intraplate earthquake (Figure $8 c$ ), like the 1933 Sanriku earthquake [Kanamori, 1971b]. Once decoupled, the slab may break by this type of intraplate earthquakes and sink in pieces into the mantle. It may also be possible that under such circumstances, the oceanic plate loses its support at the end and starts sinking well before it reaches the trench. Such a collapse of the oceanic plate may lead to the formation of marginal seas (Figures $8 d-8 f$ ). It has been suggested that the decoupling of the slab took place at the Ryukyu Trench at some time in the Tertiary and then the basins in the Philippine Sea were formed as the slab foundered and the trench retreated, as in the fashion suggested by Elsasser [1969] and Moberly [1972].

In such an evolutionary model, some explanation is needed to explain why progressively advanced stages are found successively from Alaska to the Ryukyu arc. One explanation is that as the subduction rate increases progressively from north to southwest along the northwestern Pacific margin, the evolutionary process has proceeded more rapidly along the margin. This explanation, however, may not apply to the South American margin, where a relatively early evolutionary stage is suggested in our model, yet the plate has been subducting for a long time with a high rate. It is possible that as Molnar and Atwater [1978] suggested, the age of the subducted plate is another factor that affects the mode of subduction.

\section{Anchored Slab Model}

This model is an alternative to the evolutionary model. The basic idea is very simple and similar to the one proposed by Moberly [1972] and Hyndman [1972]. It even resembles one of Wegener's [1924] postulates that marginal seas form in the rear of advancing continent. 


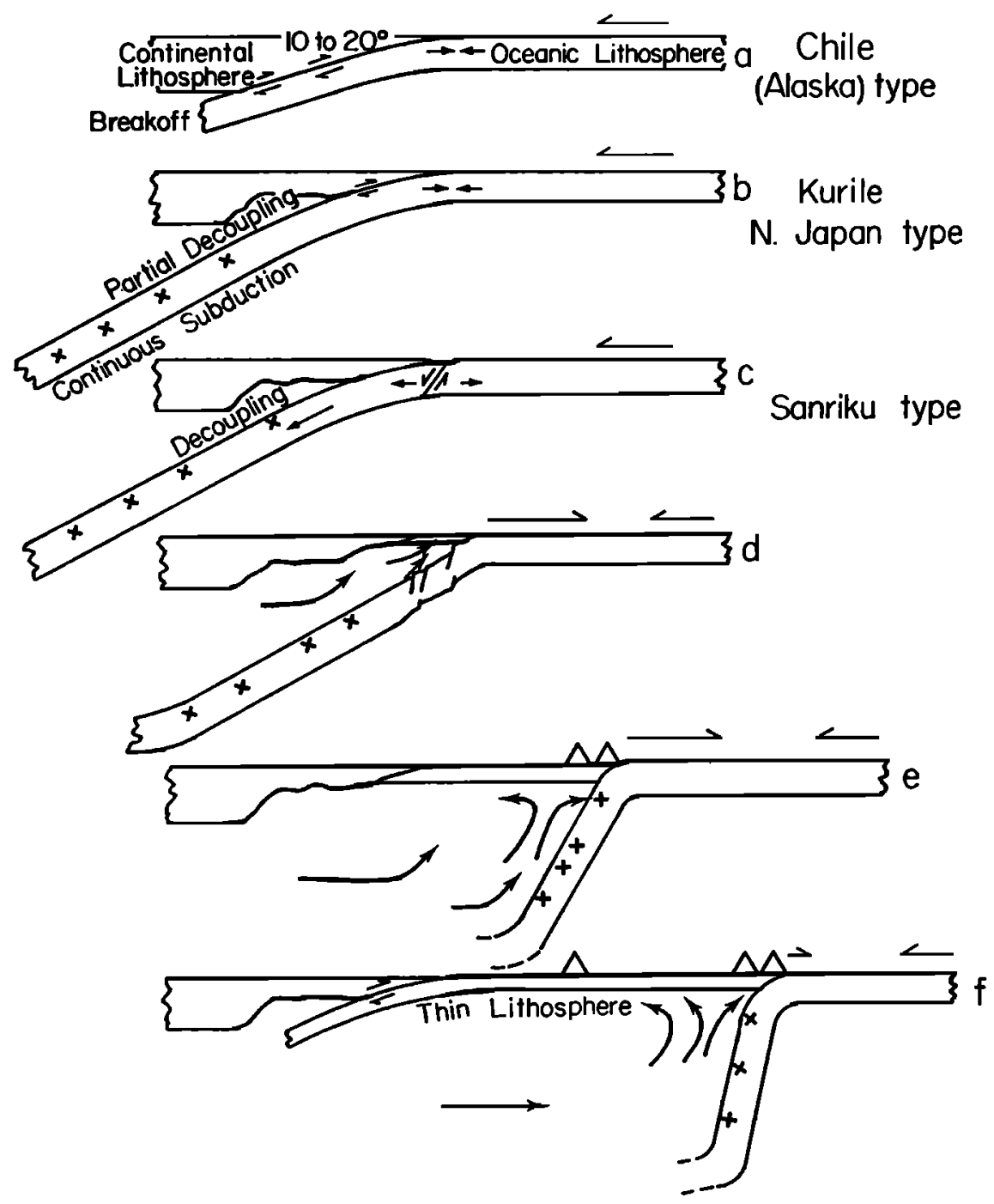

Fig. 8. Evolutionary model [Kanamori, 1977b]. (a) Strong coupling between the oceanic and continental lithospheres results in great earthquakes and breakoff of the subduction lithosphere at shallow depths. (b) Partial decoupling results in smaller earthquakes and continuous subduction. (c) Further decoupling results in aseismic events and intraplate tensional events. $(d)$ Sinking plate results in retreating subduction and formation of a new thin lithosphere. $(e)$ Episodic retreat and formation of ridges. $(f)$ Decelerated retreat and commencement of new subduction.

Referring to Figure 9, three velocities, $V_{L}, V_{U}$, and $V_{T}$, are defined. $V_{L}$ and $V_{U}$ are the velocities of the lower and the upper plates, respectively. $V_{T}$ is defined as the velocity of point $T$ where the lower plate starts deflecting downward, i.e., the position of trench. The back-arc spreading can be formulated in terms of $V_{U}$ and $V_{T}$. Namely, the condition for the back-arc

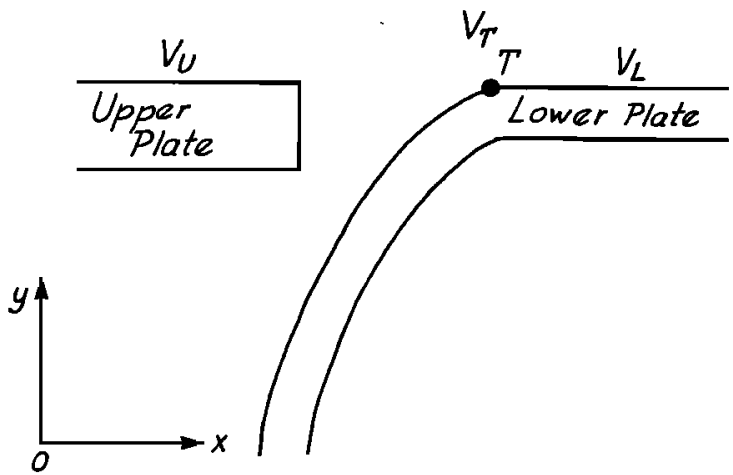

Fig. 9. Anchored slab model. to open is $V_{U}<V_{T}$. In this model, $V_{L}$ is not important except that $V_{U}$ must exceed $V_{L}$ for the boundary to be convergent. At this point, we assume that the position of the trench is fixed to the mantle. This assumption seems reasonable because it would be very difficult for the slab to move in the direction perpendicular to the strike of the trench. Thus the slab acts as an anchor [Talwani, 1969; Tullis, 1972]. In a frame of reference fixed to the mantle, we may put $V_{T}=0$. In this case, the criterion for opening of back-arc basin would become

Opening

$$
V_{U}<0
$$

Not opening

$$
V_{U}>0
$$

This criterion is testable if we know the plate motions relative to the mantle, or 'absolute motions.' Figure 10 shows the absolute motions of upper plates at subduction zones computed from model AMI of Minster et al. [1974]. Absolute motion of the Philipine Sea plate is not well determined, 


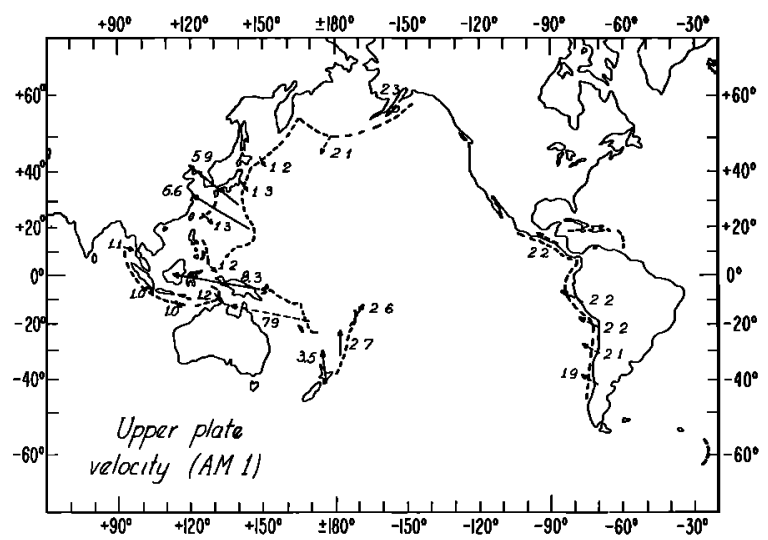

Fig. 10. Absolute velocity vectors of landward (upper) plates at subduction boundaries (after AM1 of Minster et al. [1974] and Fitch [1972]). Units are centimeters per year.

although several attempts have been made [Fitch, 1972; Morgan, 1972; Seno, 1977]. Here we used one of Fitch's models. Seno's motion is not to be used here because it relies on the relative motion at the Izu-M ariana boundary and assumption of nonspreading Mariana Trough. However, in fact, since all the models indicate substantial westward motion of the Philippine Sea plate, our discussion is not affected by the choice of the model. It appears that the above criterion for 'active' backarc is almost perfectly valid. At the Chilean arc, the South American continent is moving westward and overriding the trench, while at the Marianas arc, the upper plate is fairly rapidly retreating from the trench, and most of the intermediate cases are also quite supportive of the model. In the Andaman and Tonga areas, though marginal, the upper plate is moving away from the trench, whereas in the areas of the Aleutian, Kurile, and Japan trenches the upper plates are moving toward the trenches, but their velocities are small. The only case where the model is not supported is the Ryukyu arc. As the absolute plate motions are not accurate to $1 \mathrm{~cm} / \mathrm{yr}$, the Ryukyu situation may not be too serious. Since the trenchward velocity of the upper plate (Eurasia plate) at the Kurile and Japan trenches is also of the order of $1 \mathrm{~cm} / \mathrm{yr}$, it may be quite possible that slight changes in the motion of the Eurasia plate could have made its velocity landward in the past. This would explain how the Kurile and Japan basins were formed at some past time and are now inactivated. In the case of the New Hebrides arc, the motion of the upper plate (Fiji Plateau) is unclear. If it were fixed to the Pacific Plate as in the case shown in Figure 10, the New Hebrides back-arc should not be spreading.

In this model, tension tectonics in the back-arc region are not a direct result of the subduction of a slab. The subducting slab-the anchor-only fixes the trench position to the mantle, and the development of tensional tectonics is determined by the motion of the upper plate. Of course, not all the trenches are fixed to the mantle; the slab plays the role of the anchor effectively only at the Mariana type boundaries.

In the present model, the mantle is considered stationary for simplicity. If some flow exists in the mantle, the slab and trench would be moved along with the flow [Hager and $O^{\prime} \mathrm{Con}$ nell, 1978]. When the downgoing slab is short, as in the case of Scotia arc, flow in the asthenosphere may have a large effect. In fact, although the Scotia plate is probably moving westward with a small velocity, the Sandwich plate and the trench may be moving eastward if the Scotia ridge is really spreading as fast as $8 \mathrm{~cm} / \mathrm{yr}$ [Barker, 1970; Forsyth, 1975].
At the Chilean type boundaries, the upper plate overrides the trench so that the trench is forced to move with the speed of the upper plate. It can easily be seen, in such cases, the Benioff-Wadati zone would dip at a shallow angle. In our model, opening by back-arc spreading and opening by leaky transform faults are considered as being caused by the same ultimate mechanism, the motions of large plates. Since ordinary ocean floor spreading is also considered to be caused by the divergent motions of plates in a similar way, we may even be able to generalize that all these processes are essentially alike.

Finally, it should be noticed that the present model is quite different from that of Wilson and Burke [1972], in which the two types of subduction tectonics are assumed to be caused by whether the continental plate or the oceanic plate is advancing at the convergent boundaries. It might be pointed out that the Nazca plate is advancing toward South America as fast as the Pacific plate is advancing toward Asia.

\section{Modified Anchor Model (Lithospheric \\ Rotation Model or Counter Flow Model)}

One notable feature of trench-arc-back-arc systems around the Pacific, the east-west asymmetry, has been pointed out by several authors [e.g., Nelson and Temple, 1972; Moore, 1973]. Arcs with an active back-arc basin tend to have a west dipping high-angle downgoing slab, whereas arcs with inactive backarc have an east dipping low-angle slab. Some of the models [Nelson and Temple, 1972; Moore, 1973] imply that there is an eastward motion of asthenosphere relative to the lithosphere causing the situation illustrated in Figure 11. The absolute plate motion model AMI of Minster et al. [1974] is based on the hot spot frame of reference and in fact has a net almost westward lithospheric rotation $\left(129^{\circ} \mathrm{E}, 74^{\circ} \mathrm{S}\right.$ as the Euler pole) of $0.11 \% \mathrm{~m}$.y. If the lithosphere has a net westward rotation, it would be in some way related to the earth's rotation and tidal effects [Bostrom, 1971; Moore, 1973]. This point will be the matter of future investigation both observationally and theoretically.

In our model, so far, the downgoing slab has been considered fixed to the deep mantle. However, it may be fixed to the asthenosphere. If this were the case, the movement of the trench would be controlled by the flow in the asthenosphere. We are unable to assess the velocity of such asthenospheric flow, but if we simply assume that the flow is the counter flow to balance the westward lithospheric rotation and the thickness of the asthenosphere is comparable to that of the lithosphere, the velocity may be similar to $0.11 \% \mathrm{~m} . \mathrm{y}$. This would mean that the trenches are moving eastward with this speed relative to the deep mantle. The relative velocities of the upper plates with respect to the corresponding trenches computed on this model are as shown in Figure 12. The general situation does not differ greatly from that in Figure 10, but the Tonga and Ryukyu areas become more conformable with our ideas.

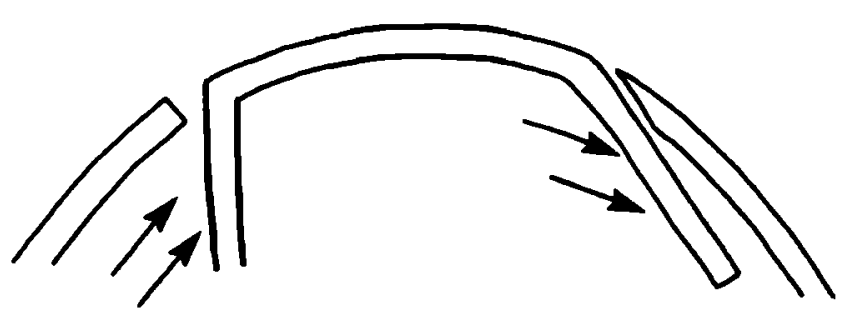

Fig. 11. An interpretation for the east-west asymmetry. 


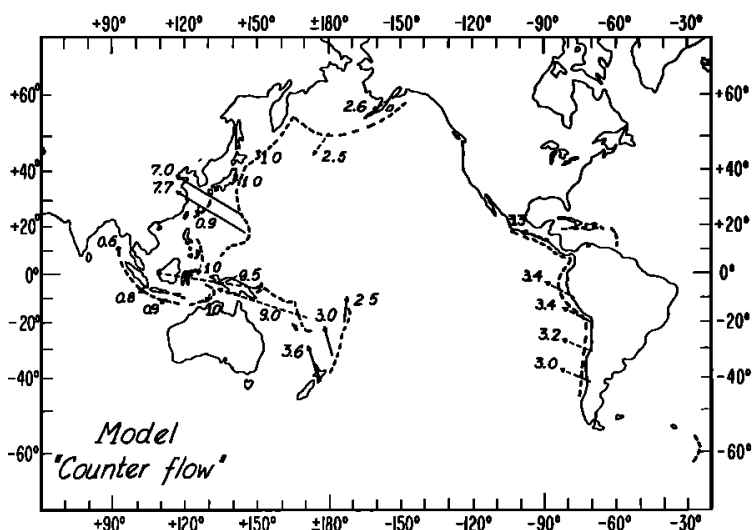

Fig. 12. Velocity vectors of landward (upper) plates relative to trenches in counter flow model. Units are centimeters per year.

\section{Conclusions}

Subduction plate boundaries can be classified into two groups according to whether their back-arc regions are actively spreading or not. The typical cases are the Mariana and the Chile boundaries. Intraplate earthquake mechanisms show that these two classes of back-arc regions are actually under tensional and compressional tectonic stresses. Great thrust type interplate earthquakes are occurring only along the latter type of subduction boundaries, indicating that there is a significant difference in the degree of coupling of the upper and lower plates between the Mariana type and the Chilean type boundaries. This in turn indicates that the mode of subduction is different in the two cases. The different cases are interpreted as caused by either differences in the stage of subduction process (evolutionary model) or differences in the motion of the landward plate (anchored slab model).

Acknowledgments. This study was conducted while Seiya Uyeda was at the Seismological Laboratory, California Institute of Technology, as a Sherman Fairchild Distinguished Scholar. We thank Seth Stein, Robert Geller, and Don Anderson for helpful comments on the manuscript. We also thank Seth Stein for his assistance in computing plate motions. This work was partially supported by a grant from the National Science Foundation, EAR76-14262. Contribution 3012 of the Division of Geological and Planetary Sciences, California Institute of Technology, Pasadena, California, 91125.

\section{REFERENCES}

Ansell, J. H., and E. G. C. Smith, Detailed structure of a mantle seismic zone using the homogeneous station method, Nature, 253. 518-519, 1975.

Atwater, T., Implications of plate tectonics for the Cenozoic tectonic evolution of western North America, Geol. Soc. Amer. Bull., 8I, 3513-3535, 1970.

Averyanova, V. N., Seismic Foci in the Far East, p. 207, Ketter Press, Jerusalem, 1973.

Barazangi, N., and J. Dorman, World seismicity map compiled from ESSA Coast and Geodetic Survey epicenter data, 1961-1967, Bull. Seismol. Soc. Amer., 59, 369-380, 1969.

Barker, P. F., A spreading center in the East Scotia Sea, Earth Planet. Sci. Lett., 15, 123-132, 1970.

Barker, P. F., and D. H. Griffiths, The evolution of the Scotia Ridge and Scotia Sea, Phil. Trans. Roy. Soc. London, 271, 151-183, 1972.

Beloussov, V. V., Some problems of development of the earth's crust and upper mantle of oceans, in The Crust and Upper Mantle of the Pacific Area, Geophys. Monogr. Ser., vol. 12, edited by L. Knopoff, and P. Hart, pp. 449-459, AGU, Washington, D. C., 1968.

Beloussov, V. V., and E. M. Ruditch, Island arcs in the development of the earth's structure, J. Geol., 69, 647-658, 1961.

Ben-Avraham, Z., and S. Uyeda, The evolution of the China Basin and the Mesozoic paleogeography of Borneo, Earth Planet. Sci. Lett., 18, 365-376, 1973.
Bostrom, R. C., Westward displacement of the lithosphere, Nature, 234, 356-538, 1971.

Caldwell, J. G., W. F. Haxby, D. E. Karig, and D. L. Turcotte, On the applicability of a universal elastic trench profile, Earth Planet. Sci. Lett., 31. 239-246, 1976.

Chase, C. G., Tectonic history of the Fiji Plateau, Geol. Soc. Amer. Bull., 82, 3087-3110, 1971.

Christiansen, R. L., and P. W. Lipman, Cenozoic volcanism and plate tectonic evolution of the western United States, II, Late Cenozoic, Phil. Trans. Roy. Soc. London, 271. 249-284, 1972.

Chung, W. Y, and $H$. Kanamori, Subduction process of a fracture zone and aseismic ridges-The focal mechanism and source characteristics of the New Hebrides earthquakes of Jan. 19, 1969 and some related events, Geophys. J. Roy. Astron. Soc., 54, 221-240, 1978.

Coleman, P. J., and G. H. Packham, The Melanesian borderlands and India-Pacific plates' boundary, Earth. Sci. Rev., 12, 197-233, 1976.

Connelly, J. B., Tectonic development of the Bismarck Sea based on gravity and magnetic modeling, Geophys. J. Roy. Astron. Soc., 46, 23-40, 1976.

Cooper, A. K., M. S. Marlow, and D. W. Scholl, Mesozoic magnetic lineations in the Bering Sea marginal basins, J. Geophys. Res., 8I, 1916-1934, 1976.

Cormier, V. F., Tectonics near the junction of the Aleutian and Kurile-Kamchatka arcs and a mechanism for middle Tertiary magmatism in the Kamchatka Basin, J. Geophys. Res., 80, 443-453, 1975 .

Curray, J. R., D. G. Moore, L. Lawver, F. Emmel, R. W. Raitt, and M. Henry, Tectonics of the Andaman Sea and Burma, Amer. Ass. Petrol. Geol. Bull., in press, 1979.

Dewey, J. W., and S. T. Algermissen, Seismicity of the middle America arc-trench system near Managua, Nicaragua, Bull. Seismol. Soc. Amer., 64, 1033-1048, 1974.

Dickinson, W. R., Relations of andesites, granites and derivative sandstones to arc-trench tectonics, Rev. Geophys. Space Phys., 8, 813-860, 1970.

Dubois, J., Propagation of $P$ waves and Rayleigh waves in Melanesia: Structural implications, J. Geophys. Res., 76, 7217-7240, 1971.

Dugas, F., J. Dubois, A. Lapouille, R. Louat, and C. Revenne, Structural characteristics and tectonics of an active island arc-The New Hebrides, in Proceedings of the International Symposium of Geodynamics of the Southwest Pacific, pp. 79-90, Technip, Paris, 1977.

Eguchi, T., S. Uyeda, and T. Maki, Seismotectonics and spreading history of Andaman Sea, Tectonophysics, in press, 1979.

Elsasser, W. M., Convection and stress propagation in the upper mantle, in The Application of Modern Physics to the Earth and Planetary Interiors, edited by S. K. Runcorn, pp. 223-246, Interscience, New York, 1969.

Engdahl, E. R., N. H. Sleep, and M. T. Lin, Plate effects in north Pacific subduction zones, Tectonophysics, 37, 95-116, 1977.

Fitch, T., Earthquake mechanisms and island arc tectonics in the Indonesian-Philippine region, Bull. Seismol. Soc. Amer., 60, 565591, 1970.

Fitch, T., Plate convergence, transcurrent faults and internal deformation adjacent to southeast Asia and the western Pacific, J. Geophys. Res., 77, 4432-4460, 1972.

Forsyth, D., An observation of compressive stress between two midocean ridges, Nature, 243. 78, 1973.

Forsyth, D. W., Fault plane solutions and tectonics of the south Atlantic and Scotia Sea, J. Geophys. Res., 80, 1429-1443, 1975.

Fukao, Y., and M. Furumoto, Mechanism of large earthquakes along the eastern margin of the Japan Sea, Tectonophysics, 25, 247-266, 1975.

Gedney, L., Tectonic stresses in southern Alaska in relationship to regional seismicity and the new global tectonics, Bull. Seismol. Soc. Amer., 60, 1789-1802, 1970.

Getts, T. R., Gravity and tectonics of the Peru-Chile Trench and eastern Nazca Plate $0-33^{\circ} 30^{\prime}$ S, Ph.D. thesis, Univ. of Hawaii, Honolulu, 1975.

Gutenberg, B., and C. F. Richter, Seismicity of the Earth and Associated Phenomena, 310 pp., Princeton University Press, Princeton, N. J., 1954.

Hager, B. H., and R. J. O'Connell, Subduction zone dip angles and flow driven by plate motion, Tectonophysics, 50, 111-133, 1978.

Hamilton, W., Earthquake map of the Indonesian region, Map I-875. C, U.S. Geol. Surv., Reston, Va., 1974.

Hanks, T. C., The Kurile Trench-Hokkaido rise system: Large shallow 
earthquakes and simple models of deformation, Geophys. J. Roy. Astron. Soc., 23, 173-189, 1971.

Hasebe, K., N. Fujii, and S. Uyeda, Thermal processes under island arcs, Tectonophysics, 10, 335-355, 1970.

Hawkins, J. W., Jr., Geology of the Lau Basin, a marginal sea behind the Tonga arc, in The Geology of Continental Margins, edited by C. A. Burk and C. L. Drake, pp. 505-520, Springer, New York, 1974.

Heezen, B., et al., Initial Report of the Deep Sea Drilling Project, vol. 6, pp. 293-388, U.S. Government Printing Office, Washington, D. C., 1971.

Herman, B. M., R. N. Anderson, and M. Truchan, Extensional tectonics in Okinawa Trough, Amer. Ass. Petrol. Geol. Bull., in press, 1979.

Hilde, T. W. C., and J. M. Wageman, Structure and origin of Japan Sea, in The Western Pacific, edited by P. J. Coleman, Pp. 415-434, University of Western Auistralia Press, Nedlands, 1973.

Hilde, T. W. C., S. Uyeda, and L. Kroenke, Evolution of the western Pacific and its margin, Tectonophysics, 38, 145-165, 1977.

Honda, H., A. Masatsuka, and M. Ichikawa, On the mechanism of earthquakes and the stresses producing them in Japan and its vicinity, 3, Geophys. Mag.. 33, 271-279, 1967.

Hyndman, R., Plate motions relative to the deep mantle and the development of subduction zones, Nature, 238, 1972.

Ichikawa, M., Mechanism of earthquakes in and near Japan and related problems, in The Earth's Crust and Upper Mantle, Geophys. Monogr. Ser., vol. 13, edited by P. Hart, AGU, Washington, D. C., 1969.

Isacks, B. L., and M. Barazangi, Geometry of Benioff zones, lateral segmentation and downwards bending of the subducted lithosphere, in Island Arcs, Deep Sea Trenches and Back-Arc Basins, Maurice Ewing Ser., vol. 1, edited by M. Talwani and W. C. Pitman III, pp. 99-114, AGU, Washington, D. C., 1977.

Isacks, B., and P. Molnar, Distribution of stresses in the descending lithosphere from a global survey of focal mechanism solution of mantle earthquakes, Rev. Geophys. Space Phys., 9. 103-174, 1971.

Ishida, M., Seismicity and travel-time anomaly in and around Japan, Bull. Earthquake Res. Inst. Tokyo Univ., 48, 1032-1051, 1970.

Kanamori, H., Great earthquakes at island arcs and the lithosphere, Tectonophysics, 12, 187-198, 1971a.

Kanamoti, H., Seismological evidence for a lithospheric normal faulting-The Sanriku earthquake of 1933, Phys. Earth Planet. Interiors, 4. 289-300, $1971 b$.

Kanamori, H., The energy release in great earthquakes, J. Geophys. Res., 82, 2981-2987, 1977a.

Kanamori, H., Seismic and aseismic slip along subduction zones and their tectonic implications, in Island Arcs, Deep Sea Trenches and Back-Arc Basins, Maurice Ewing Ser., vol. I, edited by M. Talwani and W. C. Pitman III, pp. 162-174, AGU, Washington, D. C., $1977 b$.

Kanamori, H., Quantification of earthquakes, Nature, 27I, 411-414, 1978.

Karig, D. E., Ridges and basins of the Tonga-Kermadec island-arc system, J. Geophys. Res., 75, 239-254, 1970.

Karig, D. E., Structural history of the Mariana Island Arc system, Geol. Soc. Amer. Bull., 82, 323-344, 1971 a.

Karig, D. E., Origin and development of marginal basins in the western Pacific, J. Geophys. Res., 76, 2542-2561, 1971 b.

Karig, D. E., Remnant arcs, Geol. Soc. Amer. Bull., 83, 1057-1068, 1972 .

Karig, D. E., and J. Mammerickx, Tectonic framework of the New Hebrides Island arc, Mar. Geol., 12, 187-205, 1972.

Karig, D. E., and G. F. Sharman III, Subduction and accretion in trenches, Geol. Soc. Amer. Bull., 86, 377-389, 1975.

Karig, D. E., J. G. Caldwell, and E. M. Parmentier, Effects of accretion on the geometry of the descending lithosphere, J. Geophys. Res., 81, 6281-6291, 1976.

Katsumata, M., and L. R. Sykes, Seismicity and tectonics of the western Pacific: Izu-Mariana-Caroline and Ryukyu-Taiwan regions, J. Geophys. Res., 74, 5923-5948, 1969.

Kobayashi, K. and N. Isezaki, Magnetic anomalies in Japan Sea and Shikoku Basin and their possible tectonic implications, in The Geophysics of the Pacific Ocean Basin and Its Margin. Geophys. Monogr. Ser., vol. 19, edited by G. H. Sutton, M. H. Manghnani, and R. Moberly, pp. 235-251, AGU, Washington, D. C., 1976.

Katsumata, M., and L. R. Sykes, Seismicity and tectonics of the western Pacific: Izu-Mariana-Caroline and Ryukyu-Taiwan regions, J. Geophys. Res., 74, 5923-5948, 1969.
Lahr, J. C., Detailed seismic investigation of Pacific-North American plate interaction in South Alaska, Ph.D. thesis, Columbia Univ., New York, 1975.

Larson, R. L., Bathymetry, magnetic anomalies and plate tectonic history of the mouth of the Gulf of California, Geol. Soc. Amer. Bull., 83, 3345-3360, 1972.

Lawver, L. A., and J. W. Hawkins, Diffuse magnetic anomalies in marginal basins: Their possible tectonic and petrologic significance, Tectonophysics, 45, 323-339, 1978.

Louden, K., Magnetic anomalies in the western Philippine Basin, in The Geophysics of the Pacific Basin and Its Margin. Geophys. Monogr. Ser., vol. 19, edited by G. Sutton, M. H. Manghnani, and R. Moberly, pp. 253-267, AGU, Washington, D. C., 1976.

Luyendyk, B. P., W. F. Brgan, and P. A. Jezek, Shallow structure of New Hebrides Island Arc, Geol. Soc. Amer. Bull., 85, 1287-1300, 1974.

M alfait, B. T., and M. G. Dinkelman, Circum-Caribbean tectonic and igneous activity and the evolution of the Caribbean plate, Geol. Soc. Amer. Bull., 83, 251-272, 1972.

Matsuda, T., and S. Uyeda, On the Pacific-type orogeny and its model-extension of the paired belts concept and possible origin of marginal seas, Tectonophysics, 11, 5-27, 1971.

Matumoto, T., and G. V. Latham, Aftershocks of the Guatemalan earthquake of February 2, 1976, Geophys. Res. Lett., 3, 599-603, 1976.

McKenzie, D. P., Speculations on the consequences and causes of plate motions, Geophys. J. Roy. Astron. Soc., 18, 1-32, 1969.

McKenzie, D. P., and W. J. Morgan, Evolution of triple junctions, Nature, 224, 125-133, 1969.

Mendiguren, J. A., Focal mechanism of a shock in the middle of the Nazca plate, J. Geophys. Res., 76, 3861-3879, 1971.

Minster, J. B., T. H. Jordan, P. Molnar, and E. Haines, Numerical modeling of instantaneous plate tectonics, Geophys. J. Roy. Astron. Soc. 36, 541-576, 1974.

Miyashiro, A., Volcanic rock series and tectonic setting, Annu. Rev. Earth Planet. Sci., 3, 251-269, 1975.

Moberly, R., Origin of lithosphere behind island arcs, with reference to the western Pacific, Geol. Soc. Amer. Mem., 132, 35-55, 1972.

Molnar, P., and T. Atwater, Interarc spreading and cordilleran tectonics as alternates related to the age of subducted oceanic lithosphere, Earth Planet. Sci. Lett., 41, 330-340, 1978.

Molnar, P., and L. R. Sykes, Tectonics of the Caribbean and Middle America regions from focal mechanism and seismicity, Geol. Soc. Amer. Bull., 80, 1639-1684, 1969.

Moore, G. W., Westward tidal lag as the driving force of plate tectonics, Geology. I, 99-100, 1973.

Morgan, W. J., Plate motions and deep mantle convection, Geol. Soc. Amer. Mem., 132, 7-22, 1972.

Nakamura, K., Arrangement of parasitic cones as a possible key to regional stress field, Bull. Volcanol. Soc. Jap. (in Japanese with English abstract), 14, 8-20, 1969.

Nakamura, K., K. H. Jacobs, and J. N. Davies, Volcanoes as possible indicators of tectonic stress orientations-Aleutian and Alaska, Pure Appl. Geophys., 115, 87-112, 1977.

Nelson, T. H., and P. G. Temple, Mainstream mantle convection: A geologic analysis of plate motion, Amer. Ass. Petrol. Geol. Bull., 56, 226-246, 1972

Ota, Y., and Y. Naruse, Coastal terraces of Japan (in Japanese), Kagaku, 47, 281-292, 1977.

Plafker, G., Tectonic aspects of the Guatemala earthquake of $4 \mathrm{Feb}$. 1976, Science, 193, 1201-1208, 1976.

Richardson, R. M., S. Solomon, and N. Sleep, Intraplate stress as an indicator of plate tectonics, J. Geophys. Res., 8I, 1847-1856, 1976.

Scholz, C. H., M. Barazangi, and M. L. Sbar, Late Cenozoic evolution of the Great Basin, western United States, as an ensialic inter-arc basin, Geol. Soc. Amer. Bull., 82, 2979-2990, 1971.

Shih, T., Marine magnetic anomalies and origin of the western and northern Philippine Sea, paper presented at the Joint Annual meeting, Geol. Soc. of Amer., Geol. Ass. of Can., and Mineral. Ass. of Can., Toronto, Ont., Oct. 23-26, 1978.

Seno, T., The instantaneous rotation vector of the Philippine Sea plate relative to the Eurasian plate, Tectonophysics, 42, 209-226, 1977.

Sleep, N., and M. N. Toksoz, Evolution of marginal basins, Nature, 233, 548-550, 1971 .

Sleep, N. H., Stress and flow beneath island arcs, Geophys. J. Roy. Astron. Soc., 42, 827-857, 1975. 
Smith, R. B., Intra-plate tectonics of the western North American plate, Tectonophysics, 37, 323-336, 1977.

Stauder, W., Mechanism and partial distribution of Chilean earthquakes with relation to subduction of oceanic plate, J. Geophys. Res., 78, 5033-5061, 1973.

Stauder, W., Subduction of the Nazca plate under Peru as evidenced by focal mechanism and by seismicity, J. Geophys. Res., 80, 10531064, 1975.

Stauder, W., and L. Mualchin, Fault motion in the larger earthquakes of the Kurile-Kamchatka arc and of the Kurile-Hokkaido corner, $J$. Geophys. Res., 81, 297-308, 1976.

Sugimura, A., and S. Uyeda, Island Arcs, Japan and Its Environs, 247 pp., Elsevier, New York, 1973.

Sugisaki, R., Tectonic aspects of Andesite line, Nature Phys. Sci., 240, 109-111, 1972.

Sugisaki, R., Chemical characteristics of volcanic rocks: Relation to plate movements, Lithos, 9, 17-30, 1976.

Sykes, L. R., Seismological evidence for transform faults, sea floor spreading and continental drift, in Proceedings of NASA Symposium. History of the Earth's Crust, edited by R. A. Phinney, pp. 120-150, Princeton University Press, Princeton, N. J., 1968.

Sykes, L. R., and M. Ewing, The seismicity of the Caribbean region, J. Geophys. Res., 70, 5065-5074, 1965.

Sykes, L. R., and M. Sbar, Intra-plate earthquakes, lithospheric stresses and the driving mechanism of plate tectonics, Nature, 245 , 298-302, 1973.

Sykes, L. R., and M. L. Sbar, Focal mechanism solutions of intraplate earthquakes and stresses in the lithosphere, in Geodynamics of Iceland and North Atlantic Area, edited by L. Kristjansson, pp. $207-$ 224, D. Riedel, Hingham, Mass., 1974.

Talwani, M., Plate tectonics and deep-sea trenches (abstract), Eos Trans. $A G U, 50,180,1969$.

Tarr, A. C., World seismicity map, U.S. Geol. Surv., Reston, Va., 1974.

Taylor, F. W., and A. L. Bloom, Coral reefs on tectonic blocks, Tonga Island Arc, in Proceedings of the Third International Coral Reef Symposium. pp. 275-281, Rosenstiel School of Marine and Atmospheric Science, University of Miami, Miami, Fla., 1977.

Thompson, G. A., and D. B. Burke, Regional geophysics of the Basin and Range Province, Annu. Rev. Earth Planet. Sci., 2, 213-238, 1974.
Tomoda, Y., K. Kobayashi, J. Segawa, M. Nomura, K. Kimura, and T. Saki, Linear magnetic anomalies in the Shikoku Basin, northeastern Philippine Sea, J. Geomagn, Geoelec., 28, 47-56, 1975.

Tullis, T. E., Evidence that lithosphere slabs act as anchors (abstract), Eos Trans. $A G U^{\prime}, 53,522,1972$.

Uyeda, S., and Z. Ben-Avraham, Origin and development of the Philippine Sea, Nature, 240, 176-178, 1972.

Uyeda, S., and A. Miyashiro, Plate tectonics and the Japanese Islands: A synthesis, Geol. Soc. Amer. Bull., 85, 1159-1170, 1974.

Veith, K. F., The relationship of island arc seismicity to plate tectonics (abstract), Eos Trans. AGU. 55, 349, 1974.

Watanabe, T., M. G. Langseth, and R. N. Anderson, Heat floor in back-arc basins of the western Pacific, in Island Arcs, Deep Sea Trenches and Back-Arc Basins, Maurice Ewing Ser., vol. 1, edited by $M$. Talwani and W. C. Pitman III, pp. 137-161, AGU, Washington, D. C., 1977.

Watts, A. B., and M. Talwani, Gravity anomalies seaward of deep-sea trenches and their tectonic implications, Geophys. J. Roy. Astron. Soc., 36, 57-90, 1974.

Watts, A. B., and J. K. Weissel, Tectonic history of the Shikoku marginal basin, Earth Planet. Sci. Lett., 25, 239-250, 1975.

Watts, A. B., M. Talwani, and J. R. Cochran, Gravity field of the northwest Pacific Ocean Basin and its margin, in The Geophysics of the Pacific Ocean and Its Margin. Geophys. Monogr. Ser., vol. 19, pp. 17-34, AGU, Washington, D. C., 1976.

Wegener, A., The Origin of Continents and Oceans, Methuen, London, 1924.

Weissel, J. K., and A. B. Watts, Tectonic complexities in the South Fiji marginal basin, Earth Planet. Sci. Lett., 28, 121-126, 1975.

Wilson, J. T., A new class of faults and their bearing on continental drift, Nature, 207, 343-347, 1965.

Wilson, J. T., and K. Burke, Two types of mountain building, Nature, 239, 448-449, 1972.

Yonekura, N., Quaternary tectonic movements in the outer arc of southwest Japan with special reference to seismic crustal deformationa, Bull. 7, pp. 19-71, Dep. of Geogr., Univ. of Tokyo, Tokyo, Japan, 1975.

(Received February 7, 1978;

revised August 21, 1978;

accepted September 25, 1978.) 